\title{
Implementation of Gestalt Therapy in Counseling to Overcome Parental Divorce Trauma in Adolescents
}

\author{
Arif Fajar Romadhon* \\ Guidance and Counseling, Graduate School \\ Universitas Negeri Yogyakarta \\ Yogyakarta, Indonesia \\ ariffajar.2018@student.uny.ac.id*
}

\author{
Sigit Sanyata \\ Guidance and Counseling, Faculty of Education \\ Universitas Negeri Yogyakarta \\ Yogyakarta, Indonesia \\ sanyatasigit@uny.ac.id
}

\begin{abstract}
Families have problems that must be faced sometimes can be resolved but some cannot be resolved that can result in divorce. Divorce hurts adolescents in the form of trauma. The feeling of trauma is an unresolved problem of the past. The trauma of divorce victims creates physiological, psychological and relational disorders. This is a literature review research. Data collection uses documentation techniques by collecting various kinds of literature and articles pertaining. Literature and articles included in this research were relevant with gestalt therapy in the context of adolescent with parental divorce trauma. The results indicate that gestalt therapy is effective to help adolescents overcome their trauma. Stages of gestalt therapy for traumatized teenage victims of divorce include: 1) Rebuilding trauma boundaries. Encourage the counselee to establish self-control and a sense of security here and now; 2) Building self-function, counselee awareness, and relaxation; 3) Bring back the trauma situation and review the place and time of occurrence; 4) Overcome negative counselee emotions with an empty chair; 5) Build intrapersonal relationships with family, friends and the wider environment; 6) Reconstruct the counselee's basic beliefs and provide beliefs, positive thoughts and help find the counselee's expectations.
\end{abstract}

Keywords—gestalt therapy, trauma, divorce victim

\section{INTRODUCTION}

Through family, a person can feel the love between family members consisting of both father, mother, and child. Because family life is human nature. Family is the smallest unit in a society consisting of father, mother, and child [1, 2]. Family is often called the smallest unit of society consisting of the head of the family and several people who gather and live together in a place under a roof in a state of interdependence among members. The family is the primary or primary environment for each individual before the surrounding environment. Parents are most responsible for the development of their children, including physical and psychological needs so that children can grow and develop into a mature and harmonious person [3].

The main purpose of marriage is to form a harmonious family. Through harmonious circumstances, the family environment has a major influence on the formation of individual personalities. The family has a role that is not small in shaping the soul and personality of a child because both the merits of the person and soul of a child are very dependent on the family or both parents. If the family always instills good values into the soul of the child, of course, the child either sooner or later will have a good person and soul, on the contrary, if the family does not instill good values, then, of course, the child's personality and soul will not good [4]. In achieving these expectations, of course, in a harmonious and mutually supportive family atmosphere. The formation of a child's personality in the family environment is crucial for subsequent development, especially in adolescence.

In undergoing the household certainly cannot be separated from the problem. Problems can arise because of misunderstandings, differences in interests, and family ties have not been fostered properly. Sometimes family problems can be solved with a win-win solution but not a few family problems continue to drag on and lead to divorce. The Central Statistics Agency (BPS) in Statistics Indonesia 2018, a publication of annual statistical data compilation in Indonesia, the total number of divorce cases that occurred in Indonesia in 2017 was 374,516 divorce cases. Calculation of the percentage increase in divorce cases in Indonesia each year, it was found that an increase of 11,811 divorce cases or $3.33 \%$ from 2015 to 2016 . While the increase in 2016 to 2017 amounted to 8,862 divorce cases or $2.42 \%$ [5]. Based on data quoted by AFP on the website of the Supreme Court (MA), Wednesday (3/4/2019), as many as 419,268 couples divorced throughout 2018 [6]. From various divorce data above as a whole has increased.

Divorce parents have a very large impact and influence on children, especially in the education and selfdevelopment tasks of children and adolescents. This happens because the children and adolescence are the formations of identity towards adulthood. Children will experience the process of growth and development properly and normally due to the second factor of the parents [7]. In this phase, parents need to guide and supervise the child's growth and development process, especially entering adolescence. Adolescence is a very vulnerable age with changes in developmental tasks. Dangers that occur in the adolescent phase include two things namely physical hazards and psychological hazards. Physical hazards in the form of death, suicide, or attempted suicide, physical disability, awkwardness, and rigidity. While psychological dangers occur due to failure in carrying out developmental tasks which include irresponsibility, neglect, aggressive behavior, insecurity, always wanting to return, experiencing setbacks to the previous level, and using defense mechanisms such as rationalization, projection, delusion, and transfer [8]. The 
possibility of these dangers will be further aggravated when the parents of the child divorced.

Divorce of parents can also cause trauma disorders in children. The impact of divorce consistently causes trauma and stress thereby avoiding the relationship of the opposite sex [7]. Sadness experienced by children will have an impact on social interactions, in which children will experience a period of trauma in the lives of adolescents, such as shame (inferior) with peers or with other types. Children whose parents are divorced feel ashamed or even sad because children feel different from other friends which results in damaging the child's concept which is often followed by depression, prolonged sadness, anger, a sense of rejection, feeling inferior, and being disobedient and inclined aggressive towards social [9]. This trauma occurs because the child of a divorce victim is mentally unprepared. In other words, the child must suddenly accept the decision of divorce without having a foreshadowing of life changes after parents divorced which caused the child to experience trauma.

Trauma due to divorce will adversely affect the pattern of adolescent association in the surrounding environment if not treated immediately. The existence of guidance and counseling services is expected to be able to help the difficulties faced by adolescents, in this case, the trauma of divorce victims. Guidance and counseling services are systematic, objective, logical, and ongoing and programmed efforts undertaken by counselors or guidance and counseling teachers to facilitate the development of students or counselees to achieve independence, in the form of the ability to understand, accept, direct, make decisions, and realize responsible self to achieve happiness and well-being in his life [10]. Counselors as executors of the process of guidance and counseling services are required to master a variety of approaches in counseling. In this case, the counselor has tested the professional competency of the counselor in providing guidance and counseling services. Competencies that must be mastered by counselors or guidance and counseling teachers are one of the professional competences [11]. School counselors or guidance and counseling teachers in dealing with trauma in divorced teenagers can assist in overcoming the trauma situation. One of them uses gestalt therapy assistance. Gestalt therapy holds that individuals can overcome their life's problems, especially if they are fully aware of what is happening in and around them. Gestalt psychotherapy can understand the effects of trauma as an unfinished problem and most individuals have problems because they avoid problems rather than solve them [12]. Gestalt counseling therapy emphasizes that individuals must be able to solve various kinds of past problems that have not been resolved independently and effectively [13].

Several studies have focused on the effectiveness of gestalt therapy for divorce due to divorce for adults but not many have discussed gestalt therapy for dealing with trauma due to divorce for teenagers. This is indicated by gestalt therapy interventions capable of increasing the self-efficacy of divorced women [14]. Gestalt therapy also emphasizes here and now. The feeling of trauma due to past events (unfinished business) must be resolved right now so as not to drag on. In general, in overcoming feelings of trauma due to divorce in adolescents, the concept of gestalt therapy can be used.

\section{METHODS}

The model in this study uses a meta-analysis. Metaanalysis is a model based on the study of several research results that have similar problems or studies data longitudinally on a particular issue. Meta-analysis can simply be interpreted as an analysis of the results of a particular analysis. The instrument in this study was the researcher himself (human instrument). The stages carried out in the meta-analysis method include the process of identifying, collecting, reviewing, coding and interpreting various research studies. The various studies are usually categorized based on the publication of each journal, sample size, control group, experimental group, type of treatment, duration of treatment and others.

The steps taken in the meta-analysis are: (1) Define the topic to be examined. The problem or topic examined in this study is the implementation of gestalt therapy counseling to overcome the trauma of adolescent victims of broken home; (2) Determine the period of research results used as data sources. Research results that are used as data sources are various international and domestic journals; (3) Looking for research reports related to the problem or topic to be examined. The search was conducted from several journal sources via the internet; (4) Read the title and abstract of the research report to see the suitability of its contents with the problem to be examined, in this case, seen related to the implementation of gestalt therapy in overcoming trauma; (5) Focusing research on the problem, research methodology such as the type of research, place and time of research, methods, populations, samples, sampling techniques, data analysis techniques, and results; (6) Categorizing from each research; (7) Comparing the results of all studies according to their categories; (8) Analyzing the conclusions found by reviewing various research results so that the strengths and weaknesses of previous research can be known; (9) Conclude meta-analysis research [15].

The advantage of using a meta-analysis model is that studies are conducted by gathering a lot of research, the sample size can increase so that more variables and results can be examined more broadly. However, some things need to be considered in this method, namely: goals that have good meaning, including definitions of each variable and accurate results; identification and selection of appropriate and well-documented studies; need to evaluate the biases that arise in the identification and selection of studies; the results of the description and evaluation have various properties; justification of data analytic techniques; and the use of high sensitivity analyzes [16]. Besides, the benefits of using meta-analysis are (1) focus on data, as reflected by the operationalization of variables, the size of the effect size, and the sample size; (2) Synthesizing a variety of research literature, statistical meta-analyses using final results collected from collections of similar studies or focusing more on effect sizes rather than empirical findings; (3) Allows the combining of various results, taking into account the sample size and effect size, thus allowing studies that show insignificant effects to be analyzed along with others 
that might show significant effects; (4) Meta-analysis can focus on the cumulative impact of insignificant results that can be significant so that it is possible to see the big picture of the research landscape; (5) Providing answers to questions that are in big dispute because of conflict in the results of various studies; and (6) Meta-analysis is basically confirmation, but it can also involve exploration aspects [17].

This research data collection technique uses documentation. This documentation technique is intended by gathering various relevant journal and research documents. The population in this study is in the form of all written documents about the Gestalt approach counseling research to overcome the trauma of divorce victims. The documents obtained were in the form of relevant journal research reports both on a national and international scale between 2012 and 2017. The journals studied included five journals with the theme of a gestalt approach to overcome trauma. This research sample uses purposive sampling which means that this study emphasizes the compatibility between the main research themes with the various existing research samples. Data analysis in this study consisted of two techniques, namely in the form of quantitative data analysis and qualitative data analysis. Quantitative analysis is used as a study of the figures contained in the results of the research made in percentage. While the qualitative analysis is to analyze the data of the study results descriptively or narratively against various kinds of research found.

\section{RESULT AND DISCUSSION}

Result

The research results or research reports obtained are studies that have the same topic. Then various kinds of journals obtained were analyzed one by one to find out specifically about gestalt therapy to overcome the trauma that includes similarities and differences.

\section{Meta-Analysis Based on Research Purposes}

The various objectives regarding the implementation of gestalt therapy in international proceedings and journals have several differences. The objectives in the various studies include evaluating or testing trauma experiences and growth processes from a Gestalt perspective, analyzing the effect of Gestalt therapy on trauma victims, developing a McConville gestalt therapy model in understanding the impact of adolescent trauma, and describing the implementation of gestalt therapy to overcome trauma. The general results of various studies on 5 journals or research documentation can be explained through table 1 .

Table 1. Research Objectives of Gestalt Therapy Implementation in Overcoming Trauma

\begin{tabular}{|c|l|c|c|}
\hline No & \multicolumn{1}{|c|}{ Research Purpose } & Frequency & $\begin{array}{c}\text { Percentage } \\
(\mathbf{\%})\end{array}$ \\
\hline 1 & Evaluate / Test & 2 & 40 \\
\hline 2 & Analyzing influences & 1 & 20 \\
\hline 3 & Develop a model & 1 & 20 \\
\hline 4 & Describe & 1 & 20 \\
\hline \multicolumn{2}{r|}{ Total } & 5 & 100 \\
\hline
\end{tabular}

\section{Meta-Analysis Based on Research Design}

Looking at several types of research on the implementation of Gestalt therapy in Overcoming Trauma found using several research models or designs which include literature review or literature study, descriptive, development, case studies, and surveys. Various models or forms of exposure to the five studies on the implementation of gestalt therapy can be explained in detail in table 2 below.

Table 2. Research Design Implementation of Gestalt Therapy in Overcoming Trauma

\begin{tabular}{|c|l|c|c|}
\hline No & Research design & Frequency & $\begin{array}{l}\text { Percentage } \\
(\%)\end{array}$ \\
\hline 1 & $\begin{array}{l}\text { Nonsystematic literature } \\
\text { review / Literature study }\end{array}$ & 1 & $20 \%$ \\
\hline 2 & Descriptive & 1 & $20 \%$ \\
\hline 3 & R \&D & 1 & $20 \%$ \\
\hline 4 & Case study & 1 & $20 \%$ \\
\hline 5 & Survey & 1 & $20 \%$ \\
\hline & Total & 5 & 100 \\
\hline
\end{tabular}

\section{Meta-Analysis Based on Population/Samples}

Reviewed based on the population or sample used in various studies obtained on the implementation of gestalt therapy consisting of a collection of gestalt therapy points from various books, previous scientific studies, adolescents and parents, adolescents, and husband and wife. Analysis of five studies that have an implementation of gestalt therapy, the population or study sample can be seen in the following table 3 .

Table 3. Population/Research Sample Implementation of Gestalt Therapy in Overcoming Trauma

\begin{tabular}{|c|c|c|c|}
\hline No & $\begin{array}{c}\text { Population / Research } \\
\text { Sample } \\
\end{array}$ & Frequency & $\begin{array}{c}\text { Percentage } \\
(\%)\end{array}$ \\
\hline 1 & $\begin{array}{l}\text { Points/key of Gestalt } \\
\text { therapy: Perls, Polster, } \\
\text { Dreitzel, Hartmann-Köttek, } \\
\text { and Boeckh. }\end{array}$ & 1 & $20 \%$ \\
\hline 2 & $\begin{array}{l}\text { Study of the Institute of } \\
\text { Psychiatry, Psychology \& } \\
\text { Neuroscience (IoPPN) at } \\
\text { King's College London } \\
\text { (Children) }\end{array}$ & 1 & $20 \%$ \\
\hline 3 & Teenagers and Parents & 1 & $20 \%$ \\
\hline 4 & $\begin{array}{l}\text { A couple /Male and female } \\
\text { pair }\end{array}$ & 1 & $20 \%$ \\
\hline 5 & Teenager & 1 & $20 \%$ \\
\hline \multicolumn{2}{|r|}{ Total } & 5 & 100 \\
\hline
\end{tabular}

\section{Meta-Analysis Based on Data Collection Methods/ Techniques}

Data collection methods used in various research results obtained about the implementation of gestalt therapy consist of literature study, observation, interviews, and questionnaires. The results of a study of five studies on the implementation of gestalt therapy found the methods/data collection techniques can be seen in table 4 below. 
Table 4. Methods/Techniques of Collecting Research Data Implementation of Gestalt Therapy in Overcoming Trauma

\begin{tabular}{|c|l|c|c|}
\hline No & $\begin{array}{c}\text { Data Collection Methods / } \\
\text { Techniques }\end{array}$ & Frequency & $\begin{array}{c}\text { Percentage } \\
(\boldsymbol{\%})\end{array}$ \\
\hline 1 & Study of literature & 2 & 40 \\
\hline 2 & Observation & 1 & 20 \\
\hline 3 & Interview & 1 & 20 \\
\hline 4 & Questionnaire & 1 & 20 \\
\hline \multicolumn{2}{r}{ Total } & 5 & 100 \\
\hline
\end{tabular}

\section{Meta-Analysis Based on Data Analysis used}

Data analysis emphasized in five kinds of research on the implementation of gestalt therapy found consisted of: descriptive qualitative data analysis and data analysis Descriptive statistics and inferential statistics t-test. Some data analysis in research can be known through the following table 5 .

Table 5. Data Analysis in Research Implementation of Gestalt Therapy in Overcoming Trauma

\begin{tabular}{|c|c|c|c|}
\hline No & $\begin{array}{c}\text { Data Collection Methods / } \\
\text { Techniques }\end{array}$ & Frequency & $\begin{array}{c}\text { Percentage } \\
\text { (\%) }\end{array}$ \\
\hline 1 & Qualitative descriptive & 4 & 80 \\
\hline 2 & $\begin{array}{c}\text { Descriptive statistics and } \\
\text { inferential statistics t-test }\end{array}$ & 1 & 20 \\
\hline \multicolumn{2}{|c|}{ Total } & 1 & 100 \\
\hline
\end{tabular}

\section{Discussion}

Summarizing the results of several studies on the implementation of gestalt therapy to help adolescents overcome their trauma, we can draw several conclusions from it. First, the gestalt approach generally has a unique perspective on "negative" experiences. Human life can experience trauma and unfinished problems. Unfinished problems are defined as stresses, trauma, and conflicts in relationships that were experienced in the past but are not yet finished and still have internal effects. Relationship events can end, but inner feelings such as anger, revenge, frustration, sadness, guilt, and shame continue to be experienced. This is the effect of past problems that have not been resolved. This kind of problem can be overcome by making contact concepts. The concept of contact has important meaning for the person so that he can relate to the environment and grow and develop only through healthy contact with the surrounding environment. Following the eight main characteristics of the concept of gestalt therapy, namely awareness, building relationships, activities here and now, phenomenological, real work, attitude testing, raises a sense of sensitivity between counselor and counselee and is done through a contact process [18].

Second, assistance or counseling with gestalt therapy to assist in restoring the original psychological condition, especially victims who have experienced trauma. Selfhealing techniques in gestalt therapy can help children find awareness, experience self or internal conflict, resolve inconsistencies, and penetrate dead ends that impede the completion of unfinished business. In divorced child trauma, victims focus on preventing the occurrence of acute trauma. Gestalt counseling interventions have been shown to increase positive behavior in group therapy settings and are also associated with social problems including divorce cases [19]. Third, Mc. Conville's gestalt therapy model identifies three quality contacts in the area of adolescent-parent relations, each with different levels of parental capacity to adapt to adolescent developmental needs, from supporting adolescents to dealing with traumatic adolescents. The traumas of adolescent trauma are explored then identify the causes of hopelessness through adolescent self-experiences. Exploration of adolescent trauma can be done by raising positive expectations about life. Developing optimistic hopes and attitudes is very important when treating using gestalt therapy in counselees who live in situations of material shortage, trauma and complex dilemma problems [20]. Fourth, adolescent perceptions and adjustments to events in the form of parental divorce can be negative and positive. Teenagers can show attitudes of resistance behavior as a result of divorce. Then we need counseling through gestalt therapy for divorce victims. Changing views to be positive needs to understand the various events that cause trauma that is coded and renewed in the mind and physical individual that leads to new behavior to provide prevention and treatment for these individuals [21]. Besides, strategies for implementing counseling and parental education need to be developed and implemented to help reduce the negative effects of divorce among teenagers. Fifth, gestalt therapy can be used to overcome trauma problems faced by couples.

Therapy through the gestalt approach was introduced by Frederick (Fritz) and Laura Perls in the 1940s. Gestalt is a term in German that has no synonym or synonym in English $[22,23]$. Gestalt therapy is an approach that helps the counselee to fully focus on the present and what is happening now based on experience that has not been completed (unfinished business). The counselee is asked to reenact past experiences rather than merely explaining. Every individual has the ability and ability to assume personal responsibility. Many therapists ask about what and how because the therapist wants to develop or even raise awareness at this time [24]. Being aware is related to emotional and physical needs that help understand and recognize true feelings and help understand others. Gestalt therapy emphasizes self-support and elicits lost or unacknowledged experiences to be resolved immediately [13].

The objectives of Gestalt counseling are (1) helping the counselee to reach awareness about what and how to do in which there is an element of self-acceptance, insight, knowledge of the environment, and responsibility for choices; (2) developing the ability to interact with other people or their environment; (3) can recognize, accept, express feelings, thoughts and beliefs himself [25]. Gestalt therapy aims to make people fully aware, so they can learn to deal effectively with problems. In other words, the counselee does not depend on the decisions of others, especially emphasizing the existence of independence that must be built alone rather than on the coercion of others in dealing with every problem.

Included in the traumatic events experienced by divorce victims have memories of past incidents about the divorce of both parents. Divorce certainly has an adjustment effect on divorce victims. The process by which children, through various embarrassing experiences (trauma) can give rise to 
shame and even the whole feeling which results can be feelings of alienation, inferiority, and general self-limitation $[26,27]$. Divorce has an impact on divorce children themselves in the form of trauma resulting in alienation and limiting themselves from relationships. Adolescent perceptions of divorce highlight several positive aspects, and negative aspects [28]. The first effect is a positive effect of divorce from the perspective of adolescents. These positive views or perceptions can be built by teenagers because they gain knowledge of the background of the divorce itself. Such as a family that is too much argumentation, debate, the absence of mutual defeat, and the difficulty of communication through a divorce can all be overcome. However, not all teenage divorce victims can accept the reality experienced, giving rise to negative perceptions. Three difficulties in making adjustments in divorce are: (1) dissociative pressure that disrupts adolescent mental health and emotional strength; (2) Fear of losing strong ties with caring guardians; (3) divorce gives the wrong impression in the eyes of adolescents about one's reality [29]. Fear of being ignored, the mockery of friends and avoidance and paternal mistakes, personality, and ego strength can influence the level of adjustment [30].

The effects of traumatic experiences are explained by concepts called business or unfinished problems [31]. Trauma is an experience that creates a shock, distress, and dysregulation in human life. This trauma creates major disturbances in three main areas of experience: physiological, psychological, and relational. Trauma can be a single event, a combination of various events, or chronic situations that are negotiated repeatedly. Various experiences that are beyond the reach of adolescents' abilities and are not possible to process experiences at this time; so, teenagers enter a state of fear and being overwhelmed. The impact of trauma for each adolescent usually includes adverse effects on activities that affect selfconcept and interpersonal relationships [32]. In adolescents' lives, trauma conditions have a huge impact on their lives and patterns of relationships with others. The problem of trauma in adolescents, if it is immediately addressed, will lead to new problems, namely the emergence of posttraumatic stress disorder.

Gestalt therapy is provided by activating or bringing out all that is felt in the self. As for what exists in a person there are two choices, namely rejecting the reality that exists in him or opening up to see and accept what is happening now. The role of the counselor is to help the counselee to eliminate dependency with others to be confident in their strengths and develop more optimally. The Gestalt therapist must be active and involved with the counselee to increase awareness, freedom, and self-direction by the counselee. The therapist's job is to challenge the counselee or client with the past [13]. In this way, the counselee learns to use his consciousness fully. The therapist avoids excessive intellectualization, diagnosis, interpretation, and speech. This is done so that in the therapeutic process the counselee is comfortable and able to present problems that have long been hidden.

Implementing gestalt therapy to overcome trauma, the therapist must emphasize that the counselee must have the same vision and mission of gaining awareness of the present moment and arising and feeling inhibitors of consciousness. Gestalt therapists believe people change, develop and grow when individuals experience who they are or are aware of who they are today. This is in line with gestalt therapy looking at humans by emphasizing the concept of consciousness, being able to be responsible, personal unity and bringing back various things that hinder consciousness. Experience has an impact and influence on the present caused by the lack of completion of experience [13]. When the counselee talks about the past, the counselor can ask the counselee to revive what they are experiencing now. The counselor directs the counselee to carry the fantasy as if it is happening now.

Gestalt therapy techniques that can be used to overcome past problems that have not yet been completed include the trauma of divorce victims, including 1) Through dialogue games. The dialogue technique is done by playing an empty chair by playing top dogs and underdogs; 2) Through a reversal technique. The counselor asks the counselee to play the opposite role with the feelings that are complained of; 3 ) Through projection playing. The counselee is asked to project to others about feelings that he does not want to see or receive; 4) Stay with the juice. The counselor brings the counselee to a condition that shows unpleasant and unexpected feelings or even the counselee wants to avoid, the counselor encourages the counselee to keep or hold the juice [33].

Another stage of gestalt therapy consists of the first step, building a comfortable relationship and allowing changes in the counselee; relationship patterns created are more individualized (differ in each counselee depending on the uniqueness and problems faced by each counselee; relationship situations are emotional and intuitive. In the second step, the counselor tries to ensure that the counselee can follow the procedures that have been determined by the conditions of the counselee motivate the counselee and provide an opportunity to express his displeasure or dissatisfaction, provide breadth or autonomy for the counselee, and the counselee is allowed to reject counselor's suggestions as long as there are responsible and relevant reasons. In the third step, the counselee is encouraged to express the various feelings that are felt at present it is not telling of past experiences or hopes in the future; the counselee is allowed to experience and explore all the feelings and events of the past in the situation here and now; the counselor tries to find personal aspects the missing thing to determine what to do next. The fourth step: after the counselee understands and is aware of himself, about his actions and feelings, the counseling process has reached the final stage [34].

The application of Gestalt therapy is not always directed at dangerous emotional pressures, but rather the therapist's urge to increase and intensify the emotions felt and expressions that lead to unstable situations [35]. The counselor or therapist emphasizes the emotions felt especially in the experience of divorce trauma. The flow that can be done by the counselor in applying gestalt therapy for trauma victims due to divorce is as follows. 
1. Re-establish the boundaries of trauma. Encourage the counselee to establish self-control and a sense of security "here and now". The counselee is expected to be able to play an active role and be able to make decisions.

2. Re-develop self-function and counselee awareness, by providing interventions such as "I am safe, safe and fine" or I have the freedom to do the things I want ". In addition to these interventions, counselees are also trained to do relaxation and meditation so that the counselee's feelings are better than before.

3. Approaching or re-exploring the trauma situation by telling and re-presenting the event and reviewing the place and time of occurrence with sensations and emotions as if they were happening now. The counselor's job is to convince the counselee that he is now safe, free, safe and alive. The counselor helps the client to give a different ending and slowly escape from the trauma.

4. Overcome negative counselee's emotions with an empty chair. Let the counselee vent his emotions and the counselor must help the counselee accept his current situation and accept change. Counselors emphasize that life is now better and will be lived. The counselor or therapist can combine other techniques if needed.

5. Re-establish intrapersonal relationships with family, friends and a wider scope. Feelings of love and having someone can help the healing process with extraordinary. Regarding the family, the counselee in the previous stage must be able to accept the reality of the divorce of both parents. At this stage, the counselee is asked to build relationships with both parents.

6. Redesigning back basic beliefs that exist in the counselee and provide new beliefs, positive thoughts and help find good expectations for counselees [36].

Gestalt therapy is not limited to doing in training institutions but can also be done in an academic or school environment [37]. Gestalt therapy can be applied in providing guidance and counseling services, especially in dealing with the trauma of adolescent divorced victims. School counselors or therapists apply gestalt therapy through services in either individual or group settings [24]. Individual settings can be applied by exploring trauma and counselees are given the freedom to express themselves in various gestalt techniques. Meanwhile, the group setting emphasizes the social dynamics between group members. Group dynamics arise when other members provide feedback on individual problems based on their individual experiences. Through gestalt therapy counseling services are expected to help deal with the personal and social problems of adolescents, especially related to divorce cases. So that adolescents can achieve physical and psychological wellbeing.

\section{CONCLUSION}

Based on summary drawn from five research involving gestalt therapy in adolescent with divorce trauma, gestalt therapy has an effective performance in dealing with cases of trauma to children, adolescents, and even adults. This study specifically addresses trauma treated using gestalt therapy as a result of parental divorce upon their teens.
More specifically how to deal with divorce trauma as follows. 1) Rebuilding trauma boundaries. The counselee is expected to be able to play an active role and be able to make decisions; 2) Rebuild self-function and counselee awareness, by providing interventions such as the statement states "I am safe, safe and fine" or I have the freedom to do the things I want". In addition to these interventions, counselees are also trained to do relaxation; 3) Re-approach the trauma situation by recounting and representing the event again and reviewing the place and time of its occurrence with sensations and emotions as if they were happening now. The counselor helps the client to give a different ending and slowly escape from trauma; 4) Overcome negative counselee emotions with an empty chair. Let the counselee vent his emotions and the counselor must help the counselee accept his current situation and accept change. Counselors emphasize that life is now better and will be lived; 5) Rebuilding intrapersonal relationships with family, friends and wider scope. Regarding the family, the counselee in the previous stage must be able to accept the reality of the divorce of both parents. The counselee is asked to build relationships with both parents; 6) Reconstructing the counselee's basic beliefs, giving confidence, and positive thoughts and helping to find the counselee's hopes. Gestalt therapy can be done in individual settings and group settings in guidance and counseling services at school.

\section{ACKNOWLEDGMENT}

The writer would like to thank colleagues for the discussion, input, and review of the comprehensive Gestalt Therapy.

\section{REFERENCES}

[1]. N. L. Lubis, "Memahami Dasar-dasar Konseling dalam Teori dan Praktik. Jakarta: Kencana, 2011.

[2]. D.E. Ogormegbunem, "The Changing Nature of the Family and its Duty as Foundation for Morals and Sustenance of Core Societal Value". Journal of Sociology and Social Work. Vol. 2 (1), pp. 195-209, March 2014.

[3]. Y. Singgih D. Gunarsa and Singgih D. Gunarsa "Psikologi Perkembangan Anak dan Remaja”. Jakarta: PT. BPK Gunung Mulia. 1991.

[4]. S. Sukaimi, "Peran Orang Tua dalam Pembentukan Kepribadian Anak: Tinjauan Psikologis Perkembangan Islam," Marwah, Vol 12(1), pp. 8190, Juny 2013

[5]. Anonim. (2018). Tiga Provinsi dengan Jumlah Perceraian Tertinggi. Diakses di https://smartlegal.id/smarticle/layanan/2018/12/20/tigaprovinsi-dengan-jumlah perceraian-tertinggi/. Pada 12 Juni 2019 pukul 14.00 .

[6]. A. Saputra, (2019). Hampir Setengah Juta Orang Bercerai di Indonesia Sepanjang 2018. Diakses di https://news.detik.com/berita/d4495627/hampir-setengah-juta-orang-bercerai-di-indonesia-sepanjang2018. Pada 12 Juni 2019 pukul 13.00

[7]. W. Sarbini and K. Wulandari, "Kondisi Psikologi Anak dari Keluarga yang Bercerai". Artikel Ilmiah Hasil Penelitian Mahasiswa. Fakultas Ilmu Sosial dan Ilmu Politik, Universitas Jember (UNEJ): Jember, 2014

[8]. R.E. Izzaty, S. P. Suardiman, Y. Ayriza, Purwandari, Hiryanto, R.E. Kusmaryani, Perkembangan Peserta Didik, Yogyakarta: UNY Press, 2008.

[9]. B. Gloria W \& K. Melville, Families and Intimate Relationship, New York: McGraw-Hill, Inc, 1994.

[10]. Permendikbud, Nomor 111 tahun 2014 tentang Bimbingan dan Konseling pada Pendidikan Dasar dan pendidikan Menengah, Menteri Pendidikan dan Kebudayaan: Jakarta. 
[11]. Permendiknas Nomor 27 tahun 2008 tentang Standar Kualifikasi Akademik dan Kompetensi Konselor. Menteri Pendidikan Nasional: Jakarta.

[12]. A. Gilbert., "A Phenomenological Exploration of The Impact of A Traumatic Incident (Death of A Child) on Social Services Staff'. European Journal for Qualitative Research in Psychotherapy. Vol (1), pp. 1-9, January 2006.

[13]. G. Corey, "Theory and Practice of Counseling and Psychotherapy, $10^{\text {th }}$ ed.," Boston: Cengage Learning, 2017.

[14]. H. Saadati, \& L. Lashani, "Effectiveness of Gestalt Therapy on SelfEfficacy of Divorced Women". Procedia - Social and Behavioral Sciences. Vol 84, pp. 1171 - 1174. July 2013, https://doi.org/10.1016/j.sbspro.2013.06.721

[15]. Y. W. Tumangkeng, E. Yusmin, and H, Agung, "Meta Analisis Pengaruh Media Pembelajaran terhadap Hasil Belajar Matematika Siswa," Jurnal Pendidikan dan Pembelajaran. Vol 7(6), pp. 1-9, 2008.

[16]. E. Walker, Hernandez, A. V., M. W. Kattan, "Meta-analysis: Its Strengths and Limitations," Cleveland Clinic Journal of Medicine, 75(6), pp. 431-439, June 2008.

[17]. W. R. King, \& Jun He, "Understanding the Role and Methods of Meta-Analysis in IS Research," Communications of the Association for Information Systems, Vol. 16, (32), pp. 665-686, October 2005

[18]. M. Fogarty, et al., "What do Gestalt therapists do in the clinic? The expert Consensus," British Gestalt Journal. Vol. 25(1), pp. 32-41, February 2016.

[19]. R. Raffagnino, "Gestalt Therapy Effectiveness: A Systematic Review of Empirical Evidence," Open Journal of Social Sciences, Vol 7, pp. 66-83, January 2019, https://doi.org/10.4236/jss.2019.76005.

[20]. M. Pack, "The Concept of Hope in Gestalt Therapy: Its Usefulness for Ameliorating Vicarious Traumatisation [online]. Gestalt Journal of Australia and New Zealand, Vol. 3, No. 2, May 2007: 59-71. Availability: <https://search.informit.com.au/documentSummary;dn=6397754221 44586;res=IELHEA $>$ ISSN: 1834-5298.

[21]. S. A. Maddox, J. Hartmann, R. A. Ross, "Deconstructing The Gestalt: Mechanisms Of Fear, Threat, and Trauma Memory Encoding. Neuron, Vol 102(1), pp. 60-74, April 2019. https://doi.org/10.1016/j.neuron.2019.03.017

[22]. P. Clarkson, Gestalt Counseling in Action London: Sage Publication.Cooley, C.H. 1972. Human nature on Social Order. Glen Coe, 1L: Free Press, 1989.
[23]. Bloom, Rinda, The Handbook of Gestalt Play Therapy: Practical Guidelines for Child Therapists. London: Jessica Kingsley Publishers, 2006

[24]. G. Corey, Teori dan Praktik Konseling dan Psikoterapi. Bandung: Refika Aditama, 2010.

[25]. G. Komalasari, E. Wahyu, and Karsih, Teori dan Teknik Konseling, Jakarta: Indeks, 2011

[26]. G. Kaufmann, The Psychology of Shame, New York: Springer, 1989.

[27]. P. Jenkins, "Psychology. Gestalt Couples Therapy in the Field of Trauma," Scientific Research Publishing Inc., Vol 7, pp. 695-708, May 2016.

[28]. R. M. Majzub \& S. Mansor, "Perception and Adjustment of Adolescents Towards Divorce," Procedia - Social and Behavioral Sciences, Vol 46, pp. 3530-3534, 2012.

[29]. R. D. Hess \& K.A. Camara, "Post-divorce Family Relationship as Mediating Factors In The Consequences of Divorce for Children," Journal of Social Issues. Vol 35 (4). pp. 79-98, 1979.

[30]. I. Sandler, S. Wolchik, S. Braver, \& B. Fogas, "Stability and Quality Of Life Events and Psychological Symptomatology In Children Of Divorce”. American Journal of Community Psychology, vol 19, pp. 501-520, August 1989.

[31]. E. Enil, Afşaroğlu, "Growing by Embracing and Overcoming Traumas," Journal of Modern Education Review. Vol 6 (8), pp. 578584, August 2016. Doi: 10.15341/jmer(2155-7993)/08.06.2016/008

[32]. B. Starrs, "Contact and Despair: A Gestalt Approach to Adolescent Trauma," British Gestalt Journal. Vol. 23(2), pp. 28-37, May 2014.

[33]. I. K. Rahman, "Gestalt Profetik (G-Pro) Best Practice Pendekatan Bimbingan dan Konseling Sufistik," Konseling Religi Jurnal Bimbingan Konseling Islam, [S.1.], Vol. 8,(1),pp. 51-172, Aug. 2017.

[34]. S. Mohamad, Teori-teori Konseling, Bandung: Pustaka Bani Qurani, 2003.

[35]. L. E.Wagner-Moore, "Gestalt Therapy: Past, Present, Theory, and Research," Psychotherapy: Theory, Research, Practice, Training. Vol 41, (2), pp. 180-189, 2004

[36]. E. A. E. Saliha (2017). Penerapan Therapy Gestalt Dalam Mengatasi Trauma pada Korban Child Trafficking. In Ifdil \& Krishnawati Naniek (Eds.), International Conference: 1st ASEAN School Counselor Conference on Innovation and Creativity in Counseling (pp. 39-46). Yogyakarta: IBKS Publishing. Retrieved from https://www.gci.or.id/assets/papers/ascc-2017-161.pdf

[37]. J. E. Frew, "Gestalt Therapy Training and Research: Holding Our Place at Academic Institutions in the USA," Gestalt Review. Vol. 17(3), pp. 263-271, January 2013 